症例

横行結腸切除後, 十二指腸閉塞を合併した腹部大動脈瘤の 1 例

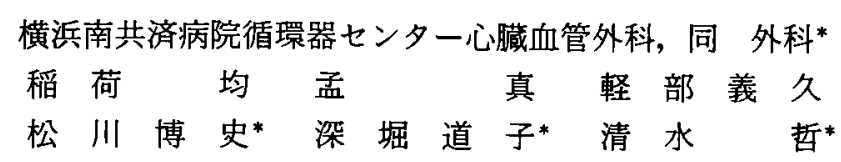

腹部大動脈瘤による十二指腸閉塞は稀である.今回, われわれは横行結腸切除術後, 腹部大動脈瘤による十二指腸閉塞をきたした症例を経験したので, 文献的考察を加えて 報告する. 症例86歳, 女性. 精查て横行結腸腫瘤, 腹部大動脈瘤, 右総腸骨動脈瘤と診 断した。 また腹部造影 $\mathrm{CT}$ 検査では腎動脈下の腹部大動脈瘤に十二指腸水平脚が圧排さ れているのを認めた。悪性腫瘍が疑われた横行結腸腫瘍の手術を先行させ, 腹部大動脈 瘤, 総腸骨動脈瘤の手術は二期的に行う方針とした。しかし横行結腸切除術後, 6 日目 にイレウスを発症し, 腹部造影 CT 検查で, 腹部大動脈瘤と腹壁に十二指腸水平脚が前 後から挟まれ閉塞していた。 十二指腸閉塞解除目的に腹部大動脈瘤, 総腸骨動脈瘤切除 人工血管置換術を施行した。術後, 十二指腸閉塞は改善した。

索引用語 : 腹部大動脈瘤, 十二指腸閉塞, 人工血管置換術

\section{緒 言}

腹部大動脈瘤による十二指腸閉塞は25例が報 告 ${ }^{1)(1)}$ され，このうちの 2 例が消化管術後の十二指腸 通過障害(例6)であった. 今回, 横行結腸切除術後, 瘾着・ 瘷痕化した大網・腸管と腹部大動脈瘤により十二指腸 が压迫され通過障害をきたした症例を経験したので報 告する.

\section{症例}

症例：86歳, 女性.

主訴：食欲不振。

既往歴: 71歳带状疮疹。

現病歴：平成16年10月はじめより食欲不振が出現し た. 同月近医を受診し, 触診で右下腹部に硬く辺縁不 整な腫瘤を指摘された。当院消化器内科を受診し腹部 エコー上最大径 $8 \mathrm{~cm}$ の腫瘤を認め, 同月精査加療目 的で入院となった.

現症：身長 $139 \mathrm{~cm}$, 体重 $36 \mathrm{~kg}$ 亀背であった。右下腹 部に径 $8 \mathrm{~cm}$ の辺緑不整な腫瘤, 臍上部に径 $5 \mathrm{~cm}$ の拍 動性の腫㾿を触知した。便通には異常がなかった。

血液検查所見 : WBC $7,300 / \mathrm{mm}^{3}, \mathrm{CRP} 0.56 \mathrm{mg} / \mathrm{dl}$

2006年 4 月19日受付 2006年6月 1 日採用

〈所属施設住所〉

₹236-0037 横浜市金沢区六浦東 $1-21-1$
と炎症所見はほほ正常範囲内であった。 RBC 362万/ $\mathrm{ul}, \mathrm{Hb} 11.1 \mathrm{~g} / \mathrm{dl}$ と軽度負血を認めた. 栄責状態は総蛋 白 $6.0 \mathrm{~g} / \mathrm{dl}$, Alb $3.2 \mathrm{mg} / \mathrm{dl}$ とやや低下していた. CEA $3.3 \mathrm{ng} / \mathrm{ml}, \mathrm{CA} 19-96.3 \mathrm{u} / \mathrm{ml}$ て腫瘍マーカーは正常範 囲内であった。

腹部造影 CT 検査所見：右側横行結腸に径 $8 \mathrm{~cm}$ の 内部不均一な腫瘤を認めた(図 1 a). 口側腸管の拡張 は認めなかった. $49 \mathrm{~mm}$ の腹部大動脈瘤, $40 \mathrm{~mm}$ の右 総腸骨動脈瘤を認めた(図 1 b). 腹部大動脈溜に圧排 された十二指腸を認めた。 十二指腸水平脚は第 4 腰椎 を横断していた（図 $1 \mathrm{c}$ ). 腹部大動脈瘤と十二指腸の 位置関係のシェーマを示した(図 $2 \mathrm{a}$ ). 腹部分枝の起 始部と腹部大動脈瘤（十二指腸）の間には十分な距離

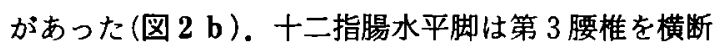

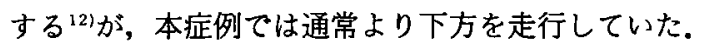

入院後経過 : 大腸内視鏡検查は腹部大動脈瘤がある ため行わなかった。術前診断は横行結腸腫瘤, $49 \mathrm{~mm} の$ 腹部大動脈瘤, $40 \mathrm{~mm}$ の右総腸骨動脈瘤であった. 腹 部大動脈瘤は年齢から考えると経過観察可能であった が, 総腸骨動脈瘤は比較的大きく破裂の可能性が高く 手術適応であると考えた. 横行結腸腫愓が悪性の可能 性が高く予後判定も必要であることから横行結腸切除 術を先行させ, 二期的に腹部大動脈瘤, 総腸骨動脈瘤 の手術の方針とした. 

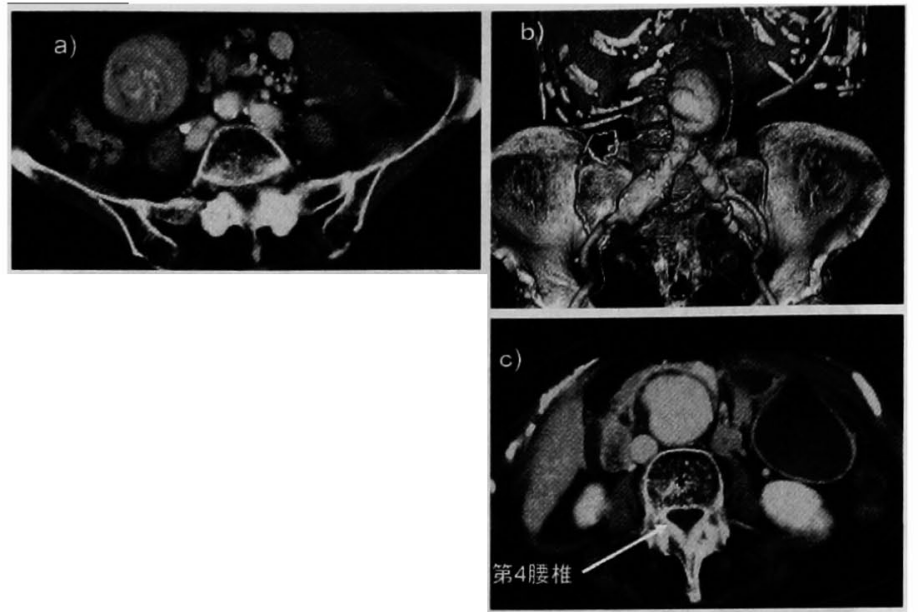

図 1 腹部造影 CT 検査：a）横行結腸に径 $8 \mathrm{~cm}$ の腫㿉を認めた， b) 49

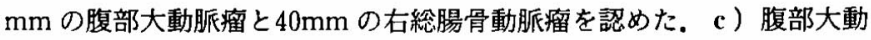
脈瘤に十二指腸が圧排されていた。 十二指腸は第 4 腰椎を横断していた。
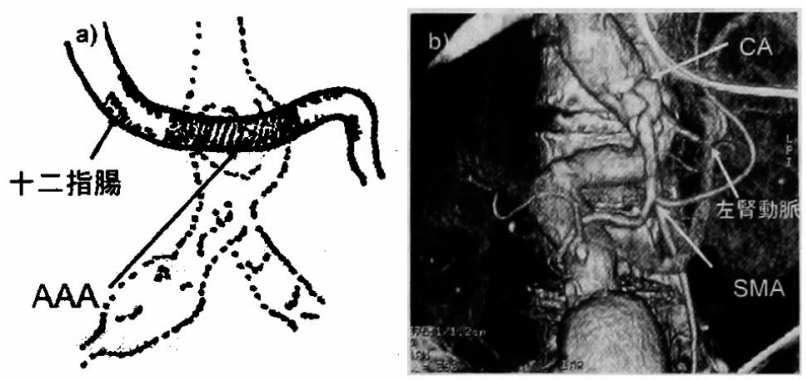

図 2 腹部大動脈瘤，十二指腸，腹部分枝の位置関係：a 腹部大 動脈痛と十二指腸の位置関倸のシェーマ， b ) 腹部分枝と腹部大 動脈㢞（十二指腸）の間には，十分な距離があった。

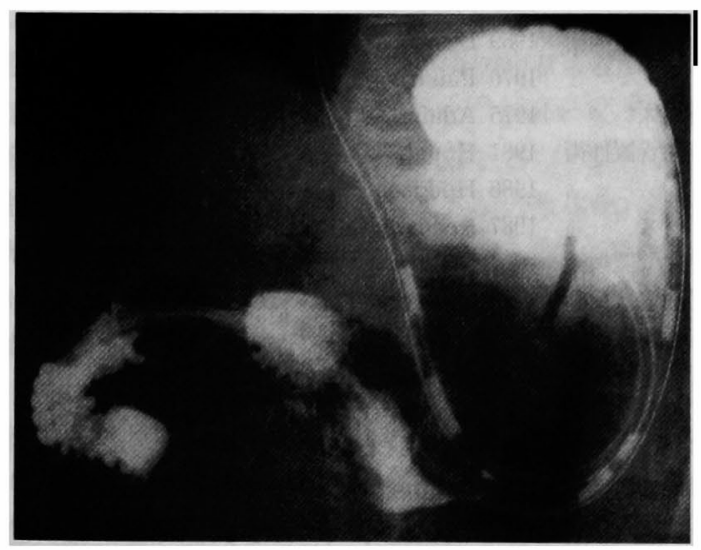

図 3 イレウス管造影：イレウス管は十二指腸水平脚ま でしか進まなかった。十二指腸水平脚の通過障害を認 めた.
初回手術：横行結腸切除術を施行した。

組織病理学的検査 : $90 \mathrm{~mm} \times 85 \mathrm{~mm}, 1$ 型高分化型腺 癌, sm, n0, ow (-), aw (-), ly0, v0. Stage I, 根 治度 Aであった.

術後経過：術後 4 日目より食事開始としたが, 術後 6 日目に嘔吐した.イレウスと診断し，胃管を挿入し た. その後絶飲食, 補液で経過観察したが, 改善しな いため術後13日目イレウス管挿入および造影を施行し た.イレウス管は十二指腸水平脚より肛門側には挿入 困難で, 造影で十二指腸水平脚の通過障害を認めた(図 3 ). 腹部造影 $\mathrm{CT}$ 検查を施行したところ, 腹壁と腹部 大動脈瘤で十二指腸が圧迫されていた（図 4 a-1, 2 ).腹部大動脈瘤が十二指腸閉塞の原因であると考え た。 

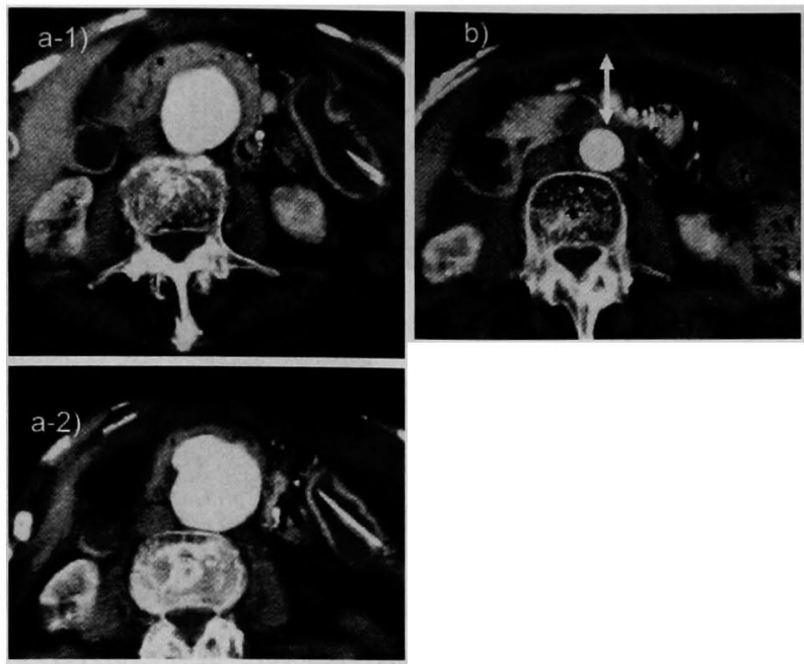

図 4 腹部造影 CT 検査

a - 1，2 腹部大動脈瘤術前：腹部大動脈瘤と腹壁で十二指腸 が圧迫されていた。

b 腹部大動脈瘤術後：腹壁と大動脈の間の距離が確保でき, 十二指腸が圧迫されなくなった。

表 1 腹部大動脈瘤による十二指腸イレウス症例 文献的報告の一覧

\begin{tabular}{|c|c|c|c|c|c|}
\hline 症例 & 年齢 & 性別 & 瘤計(mm) & 治療方針 & 報告者 \\
\hline 1 & / & 女性 & 1 & 剖検 & 1905 Osler \\
\hline 2 & / & 1 & 1 & 胃空腸バイパス & 1907 Spishary \\
\hline 3 & 67 & 女性 & 75 & 胃空腸バイパス & 1936 Washburn \\
\hline 4 & 72 & 男性 & 1 & 胃空腸バイパス & 1947 Blakemore \\
\hline 5 & 76 & 男性 & 50 & 十二指腸空腸バイパス & 1950 Dunning \\
\hline 6 & 66 & 男性 & 1 & 瘤切除人工血管置換術 & 1950 Javid \\
\hline 7 & 57 & 男性 & 1 & 瘤切除人工血管置換術 & 1950 Javid \\
\hline 8 & 62 & 男性 & 1 & 胃空腸バイパス & 1958 Eudel \\
\hline 9 & 76 & 男性 & 90 & 胃空腸バイパス & 1959 Margoles \\
\hline 10 & 54 & 男性 & 100 & 瘤切除人工血管置換術 & 1959 Desiderio \\
\hline 11 & 73 & 男性 & 125 & 不明 & 1970 Panaro \\
\hline 12 & 80 & 男性 & 126 & 胃劦腸バイパス & 1975 Adair \\
\hline 13 & 45 & 男性 & 40 & 瘤切除人工血管置換術 & 1981 Hough \\
\hline 14 & 86 & 女性 & 85 & 手術なし & 1986 Hodgson \\
\hline 15 & 87 & 男性 & 75 & 胃空腸バイパス & 1987 Redmond \\
\hline 16 & 69 & 男性 & 75 & 瘤切除人工血管㯰換術 & 1987 Redmond \\
\hline 17 & 70 & 男性 & 45 & 瘤切除人工血管置換術 & 1988 Coster \\
\hline 18 & 70 & 男性 & 70 & 瘤切除人工血管置換術 & 1988 Quigley \\
\hline 19 & 82 & 男性 & 100 & 瘤切除人工血管置換術 & 1988 Quigley \\
\hline 20 & 80 & 男性 & 80 & 初切除人工血管置換術 & 1993 Sostec \\
\hline 21 & 75 & 男性 & 60 & 溜切除人工血管置換術 & 2001 Jay K. Bhama \\
\hline 22 & 72 & 男性 & 70 & 溜切除人工血管置換術 & 2003 Dharmendran \\
\hline 23 & 70 & 男性 & 70 & 瘤切除人工血管置換術 & 2003 Michele \\
\hline 24 & 77 & 男性 & 80 & 瘤切除人工血管置換術 & 2004 安藤 \\
\hline 25 & 77 & 男性 & 80 & 㢞切除人工血管置換術 & 2004 安藤 \\
\hline
\end{tabular}


2 回目手術：十二指腸閉塞解除目的で初回術後27日 目に腹部大動脈瘾, 総腸骨動脈瘾切除人工血管置換術 を施行した，開腹すると，大網，小腸，残存横行結腸 が高度に疮着, 疫痕化しており，この痹着, 疫痕化し た大網や腸管と腹部大動脈瘤で十二指腸が圧迫されて いた。この應着を剝離し，さらに十二指腸を腹部大動 脈瘤の前壁より剝離し, 腹部大動脈瘤の中枢を確保し た。術前腹部大動脈瘤と十二指腸が高度に癒着してい ることが危惧されたが，癒着は軽度であった．Y 型人 工血管を使用し $\left(16 \mathrm{~mm} \times 8 \mathrm{~mm}\right.$ Intergard $\left.{ }^{\mathrm{R}}\right)$ 腹部大動 脈瘤，総腸骨動脈瘤切除人工血管置換術を施行した。 瘤壁，後腹膜で人工血管を被覆し，十二指腸と接しな いように注意した。

2 回目術後経過：術後 5 日目ガストログラフィンを 使用した消化管造影を施行し，十二指腸に通過障害が ないことを確認した，術後 7 日目に経口摄取を開始し た。経過良好で術後25日目に退院した。また術後腹部 造影 CT 検查でも腹壁と十二指腸の距離は十分にあ り，通過障害はないと考えた（図 4 b).

\section{考 察}

腹部大動脈瘤の発生部位は約 $95 \%$ 腎動脈分岐部よ り遠位側に発生する ${ }^{13)}$ ．そのため通常は十二指腸より 下方に腹部大動脈瘤が発生するため，十二指腸通過障 害をきたすことは極めて稀である．1905年にOsler が 剖検例で腹部大動脈瘤による上部消化管の拡張を初め て記述しだかがかれわれが検索した限りで，25例の臨 床報告があった（表 1 ）。報告例は男性が多く，平均年 齢は75歳, 初発症状は嘔吐が多く, 最大瘤径の平均は $7.8 \mathrm{~cm}(4.5 \mathrm{~cm} \sim 12.6 \mathrm{~cm})$ で，巨大な腹部大動脈瘤に より十二指腸が閉塞した例 ${ }^{10)}$ ，十二指腸が大動脈瘤前 壁, 側壁と高度に痹着し, 十二指腸が折り重なってし まい閉塞した(例4などがあった。桭腸の直下に腹 部大動脈瘤を認める場合，十二指腸閉塞の可能性を危 惧する必要があると思われた。また巨大な腹部大動脈 瘤ではないが, 腹部大動脈瘤と腹膜の先天性の策状物 によって十二指腸が閉塞した例2 などの報告も認めら れた。

イレウスを発症した場合の治療方針としては，まず 経鼻胃管，イレウス管を挿入し上部消化管の減圧を図 り改善を待つが改善がない場合は手術適応となる．腹 部大動脈瘤が巨大な場合，十二指腸を压迫しイレウス の原因となり得るので(表 1 ), 腹部大動脈瘤を切除す る必要があり，腹部大動脈瘤切除人工血管置換術が第 一選択である．十二指腸と腹部大動脈瘤が高度に癒着
していることが多いとの報告があり手術には注意が必 要である ${ }^{10)}$ 。また高齢などを理由に胃空腸バイパスな どの消化管パイパスを選択した報告例（表 1 ）もあっ た。

腹部大動脈瘤と結腸癌を合併した場合は, 手術を一 期的もしくは二期的に行うか，どちらを先行させるか などが問題となる ${ }^{1415)}$. 今回, われわれは, 人工血管移 植および同時手術による過大侵㜔手術を避けるため, 悪性腫瘍の可能性が高い横行結腸腫場の手術を先行さ せ, 術後の経過をみて腹部大動脈瘤, 総腸骨動脈瘤の 手術の方針とした. 結果的には, 横行結腸術後の大網, 小腸が痛着・疫痕化し，十二指腸の圧迫が高度となり， 術前には起きていなかった十二指腸閉塞をきたした。 大動脈瘤前面を十二指腸が走行している場合は術後十 二指腸閉塞など應着により起こることを念頭におき可 及的に疫痕が疫前面に来ないよう配慮しながら手術を 行うべきと考えた。

結語

腹部大動脈瘤と横行結腸腫瘍切除術後, 癁着, 瘢痕 による十二指腸閉塞を合併した腹部大動脈瘤の症例を 経験し, 腹部大動脈瘤切除人工血管置換術が有効であ った.

\section{文献}

1) Sostec M, Fine SN, Harris TL, et al : Duodenal Obstruction by Abdominal Aortic Aneurysm. Am J Med 94 : 220-221, 1993

2) Bhama JK, Ogren J, Guinn G, et al: Unique cause of duodenal obstruction by an abdominal aortic aneurysm. J Vas Surg 34:1130-1132, 2001

3) Hough DR, Mera TFO:Abdominal Aortic Aneurysm with Initial Symptom of Duodenal Obstruction. Am J Gastroenterol 76 : 538-541, 1981

4) Coster DD, Stubbs DH, Sidney DT : Duodenal Obstruction by Abdominal Aortic Aneurysm. Am J Gastroenterol 83 : 981-984, 1988

5) Osler W: Aneurysm of Abdominal Aorta. Lancet $14:$ 1089-1096, 1905

6) Redmond PL, Price GJ, Nolan DJ : Abdominal Aortic Aneurysm Causing Duodenal Obstruction. Clinical Radiology 38:513-514, 1987

7) Hudgson KJ, Webster DJT : Abdominal aortic aneurysm causing duodenal and ureteric 
obstruction. J Vasc Surg 3:364-368, 1986

8) Dharmendran $R$, Zainai AA : An common cause of duodeal obstruction. Med J Malaysia 58 : 135-138, 2003

9) Torella M, De Santo LS, Corte $A D$, et al : Extensive Retroperitoneal Fibrosis with Duodenal and Ureteral Obstruction. Texas Heart Inst J 30:311-313, 2003

10）安藤 敬, 幕内晴朗, 菊地慶太他：腹部大動脈瘤 による十二指腸狭窄により発症したイレウスの 2 例. 日臨外会誌 $65: 3189-3193,2004$

11) Quigley FG, Faris IB, Jamieson GG : Duodenal obstruction as the presenting symptom of aortic aneurysm. Aust N Z J Surg 58: 909-911,
1988

12）Moore KL (著), 坂井建雄 (訳)：ムーア臨床解 剖学. 医学書院, 東京, 1997, p104

13) Brewster DC, Cronenwett JL, Hallett JW, et al : Guidelines for the treatment of abdominal aortic aneurysms. J Vasc Surg 37 : 1106-1117, 2003

14) 山本尚人, 海野直樹, 三岡 博他：腹部消化器外 科疾患を合併した腹部大動脈瘤手術症例の経験. 日臨外会誌 $62: 1136-1140,2001$

15）小林利彦，山下克司，川辺昭浩 他：悪性腫瘍を伴 った腹部大動脈瘤手術症例の問題点. 外科 66 : $1079-1083,2004$

\title{
A CASE OF DUODENAL OBSTRUCTION DUE TO AN ABDOMINAL AORTIC ANEURYSM AFTER TRANSVERSE COLECTOMY
}

\author{
Hitoshi INARI, Makoto MO, Norihisa KARUBE, Hiroshi MATSUKAWA*, \\ Michiko FUKAHORI* and Satoru SHIMIZU* \\ Departments of Cardiovascular Surgery and Surgery*, Yokohama Minami Kyosai Hospital
}

Duodenal obstruction due to an abdominal aortic aneurysm is rare. We experienced a case of duodenal obstruction due to an abdominal aortic aneurysm after transverse colectomy.

An 86-year-old woman was admitted to the hospital because of anorexia and an abdominal mass. Preoperative abdominal CT scan demonstrated an abdominal mass originated from the transverse colon, an abdominal aortic aneurysm and a right common iliac artery aneurysm. Horizontal portion of duodenum ran in front of the infra-renal aortic aneurysm on contrast enhanced CT scan. Because of high probability of malignancy, transverse colectomy was performed as the first stage operation. On the 6th postoperative day obstruction of the duodenum occurred. Abdominal CT scan with contrast demonstrated a narrowing horizontal potion of duodenum which was compressed by the aortic aneurysm and abdominal wall. Open repair for the abdominal aortic aneurysm and iliac artery aneurysm was performed by using $\mathrm{Y}$ graft, resulting in an immediate relief of duodenal obstruction. 